\title{
Trends in temperature and precipitation extremes in historical (1961-1990) and projected (2061-2090) periods in a data scarce mountain basin, northern Pakistan
}

\author{
Naeem Saddique ${ }^{1,2} \cdot$ Abdul Khaliq $^{2} \cdot$ Christian Bernhofer $^{1}$
}

Published online: 24 June 2020

(c) The Author(s) 2020

\begin{abstract}
This study investigates the trends of precipitation and temperature extremes for the historical observations (1961-1990) and future period (2061-2090) in the Jhelum River Basin. Future trends are estimated by using ensemble mean of three general circulation models under RCP4.5 and RCP8.5. Therefore, statistical downscaling model has been used to downscale the future precipitation and temperature. A total of 15 precipitation and temperature indices were calculated using the RClimdex package. Man-Kendall and Sen's slope tests were used to detect the trends in climate extreme indices. Overall, the results of study indicate that there were significant changes in precipitation and temperature patterns as well as in the climate extremes in the basin for both observed as well as projected climate. Generally, more warming and increase in precipitation were observed, which increases from RCP4.5 to RCP8.5. For all the stations, increasing trends were found for both precipitation and temperature for twenty-first century at a $95 \%$ significance level. The frequency of warm days (TX90p), warm nights (TN90p), and summer days (SU25) showed significant increasing trends, alternatively the number of cold nights (TN10p) and cold days (TX10p) exhibited opposite behaviors. In addition, an increasing trend of warmest day (TXx) and coldest day (TNn) was observed. Our analysis also reveals that the number of very wet days (R90p) and heavy precipitation days $(\mathrm{R} 10 \mathrm{~mm})$ will likely increase in the future. Meanwhile, the Max 1-day (RX1-day) and 5-day (RX5-day) precipitation indices showed increasing trends at most of the stations of basin. The results of the study is of potential benefit for decision-makers to develop basin wide appropriate mitigation and adaptation measures to combat climate change and its consequences.
\end{abstract}

Keywords Temperature extremes · CMIP5 - Jhelum River basin - Climate change - Warm nights · Sen's slope

\section{Introduction}

Intergovernmental Panel on Climate Change (IPCC) points out that the climate change started to affect the frequency, intensity, and duration of extreme climate events such as droughts, floods and heat waves globally at the end of twentieth century which is likely to continue in future (IPCC 2013). Additionally, it is anticipated that any future

Naeem Saddique

Naeem.saddique@tu-dresden.de

1 Institute of Hydrology and Meteorology, Technische Universität Dresden, Tharandt, Germany

2 Department of Irrigation and Drainage, University of Agriculture, Faisalabad, Pakistan changes in mean climate values will have less negative impacts on human health and natural system than changes in extreme events (Katz and Brown 1992; IPCC 2013). It is reported in Fifth Assessment Report (AR5) that globally the number of warm days and nights has increased, whereas the number of cold days and nights has decreased between 1951 and 2010. Climate change poses serious threats to Pakistan. As such, it has caused various disasters in the form of droughts and floods in the country. In the aftermath of the 2010 floods, about $20 \%$ the country's land area was underwater; it severely damaged the infrastructure, crops and housing, impacted livelihoods over 20 million people. Due to the single flood event, estimated damages were about US\$10 billion, half of which were losses in the agriculture sector (ADB and World Bank 2010). In addition, severe heat wave that occurred in 
Pakistan during 2015 and caused about 1233 deaths (Saleem et al. 2018). During this heat wave, around 65,000 people were treated in different hospitals because of the heatstroke.

In the last decade, for analyzing the climate extremes changing patterns across the world a number of global and local studies have been reported (Islam et al. 2009; Sillmann et al. 2013; Rashid et al. 2017; Pei et al. 2017; Ongoma et al. 2018; Roxy et al. 2017; Cheong et al. 2018; Feyissa et al. 2018; Abbasnia and Toros 2018; Abatan et al. 2018; Peng et al. 2018; Fenta Mekonnen and Disse 2018; Salvador and de Brito 2018). However, the impact of climate change is not uniform globally (Sillmann et al. 2013). Islam et al. (2009) assessed that the occurrence of annual warm spells shows slight increasing trend while cold spells significantly decrease over Pakistan. Ongoma et al. (2018) found a remarkable increase in maximum 1-day and maximum 5-day precipitation amount over Kenya and Uganda. Abbasnia and Toros (2018) analyzed that the in future rainfall events will be short and intense, the occurrence of extreme temperatures could be more pronounced in favor of hotter events, and atmospheric moisture content will be increased over the Marmara Region, Turkey. Thus, this suggests that in future there will be higher occurrence probabilities of heavy rainfalls and droughts. These kind of intense climate events are always associated with social and economic losses. The impact becomes more severe if different extremes occur at the same time for instance heatwaves and meteorological droughts (Sharma and Mujumdar 2017).

Globally changes in climate extreme events associated with substantial effects on human health and the environmental system. Nevertheless, climate change has the ability to alter both frequency and intensity of climate extremes events. More severe extreme events will be occurred due more severe climate changes, causing significant consequences. Therefore, climate extremes prediction is very essential to analyze the climate change impacts on human society and on the environmental system (Mahmood and Babel 2014). This kind of information is also important for effective planning at national and local level strategies for both adaptation and mitigation (Gu et al. 2012; Frias et al. 2012; Adyeri et al. 2019).

Global climate models (GCMs) are the major tools used to reproduce observed features of present climate and project future climate (Meehl et al. 2007). However, GCMs have coarse resolution and their outputs cannot directly meet the needs of end-users who want to apply climate extremes changes in integrative studies, for instance conservation, hydrology, and climate change risk assessment (Diaz-Nieto and Wilby 2005). To fill this gap, different downscaling techniques are developed and commonly used (Wilby and Dawson 2004, 2013; Zhang et al. 2016;
Saddique et al. 2019). The downscaling methods have been divided into two main categories: statistical downscaling, establishing a relationship between large scale climate variables (vorticity and sea level pressure) and local observations like precipitation and temperature; dynamical downscaling, using GCM output to drive regional climate models (RCMs) (Turco et al. 2011; Bao et al. 2015; Chen et al. 2018). A widely used statistical tool in climate change studies is SDSM (statistical downscaling model).

One study has been undertaken only on temperature extreme indices over the Jhelum River basin (Mahmood and Babel 2014) using one GCM (HADCM3) from third Assessment report (AR3), noting an increase in temperature. To the best of our knowledge, no prior studies have been reported to date that examine the extreme precipitation events in Jhelum River basin. Precipitation is increasingly important and relevant parameter to be studied due to flash flooding and abnormal river flows in past few years in the Indus Basin including Jhelum River basin (Rehman et al. 2015). Both temperature and precipitation phenomenon are interlinked and to river flow in the region, therefore, it is justified to study both variables together for clearer picture. Thus the specific objective of the present study is to investigate the past and projected changes of both temperature and precipitation climate extremes over Jhelum River basin using the observed data and future outputs of three GCMs from CMIP5 (Coupled Model Intercomparison Project from Phase 5). First, this study investigates the trends of climate extreme indices over the study area during the observed period. After that, the downscaling method (SDSM) is employed to 2061-2090 CMIP5 runs under two RCPs scenarios and evaluates how much change occurs in climate Indices after 100 years. Fifteen (15) precipitation and temperature indices are used in the study defined by the Expert Team on Climate Change Detection Monitoring and Indices (ETCCDMI).

The rest part of this study outline is as follows: Sect. 2 briefly explains the study area and data. Section 3 explains the methodology used for downscaling GCMs outputs and climate Extremes Indices calculation. Section 4 presents and discusses results, while the conclusion of the study is described in Sect. 5.

\section{Study area and data}

\subsection{Description of the study area}

The Jhelum River Basin (JRB) lies between $73-75.62{ }^{\circ} \mathrm{E}$ and $33-35{ }^{\circ} \mathrm{N}$ with total basin area $33,397 \mathrm{~km}^{2}$. JRB has significant variation in the elevation, which varies between 232 and $6287 \mathrm{~m}$. The whole river discharge flows into the Mangla Dam reservoir, the second biggest reservoir of 
country. Locations of the study area and weather stations (temperature and precipitation) are shown in Fig. 1.

Most of the water flows into the reservoir in summer, with a substantial share due to snowmelt during the month of May. Generally, more than $2 / 3$ of the total water enters the reservoir from March to August. The Mangla Dam reservoir can irrigate up to 6 million hectares land. Reservoir water mainly used for two key purposes: supply water at downstream to irrigate the agriculture land and generate $1000 \mathrm{MW}$ electricity, which is approximately $15 \%$ of the total electricity production through hydroelectric plant in the country (Archer and Fowler 2008).

The whole basin has mean annual precipitation about $1196 \mathrm{~mm}$ and mean annual temperature $13.2{ }^{\circ} \mathrm{C}$. The climate of the Jhelum River basin (JRB) varies with elevation; northern part of the basin is colder (high altitude) than southern part. Naran with mean temperature $6.4{ }^{\circ} \mathrm{C}$ and Mangla with mean temperature $22.62{ }^{\circ} \mathrm{C}$ are the coldest and hottest stations of Jhelum River basin. Murree and Balakot are two highly rainy stations with precipitation amounts more than $1700 \mathrm{~mm} / \mathrm{year}$ (Saddique et al. 2019) (Table 1).

\subsection{Data description}

Daily observed precipitation (Prec.), Temperature maximum (Tmax) and Temperature minimum (Tmin) data of 15 stations for the period of 1961-2012 were obtained from Pakistan Meteorological Department (PMD), Water and Power Development Authority of Pakistan (WAPDA), and the Indian Meteorological Department (IMD). Precipitation and temperature data of Srinagar, Gulmarg, Qaziqund, and Kupwara meteorological stations were obtained from the IMD.

In this study, daily predictors (26) of three GCMs (i.e., CanESM2, BCC-CSM1.1, and MIROC5) from Phase 5 of the Coupled Model Intercomparison Project (CMIP5) for the period of 1961-2100 are downloaded from ESGF website (http://pcmdi9.1lnl.gov/). We used two RCPs scenarios, RCP 4.5 and RCP 8.5 , which assumes that radiative forcing would increase to $4.5 \mathrm{Wm}^{-2}$ and $8.5 \mathrm{Wm}^{-2}$, respectively, towards the end of the twenty-first century (Moss et al. 2010). Daily predictors data of NCEP (National Centers of Environmental Prediction) for the historical period (1961-2005) is obtained from SDSM website (https://sdsm.org.uk/data.html). As the GCMs data are available at different spatial resolutions, these data sets are interpolated at the grid resolution of NCEP $\left(2.5^{\circ} \times 2.5^{\circ}\right)$. GCMs predictors have been normalized with respect to their means and standard deviations (SD) for the historical period 1961-1990. Table 2 provides a detail description of global climate models.

\section{Methodology}

SDSM (statistical downscaling model) is a combination of multiple linear regression (MLR) and stochastic weather generator. In SDSM during calibration MLR establish mathematical relationship between regional predictors (i.e.,

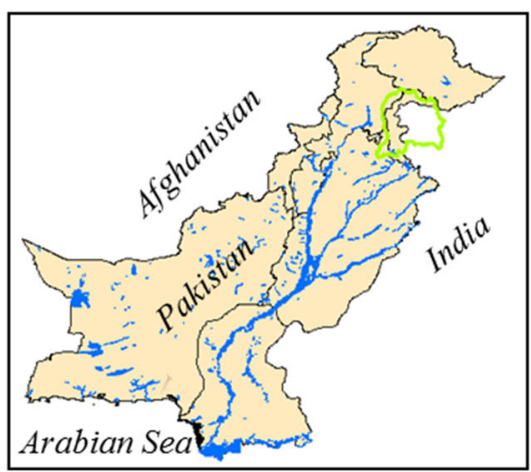

DEM

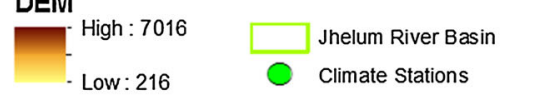

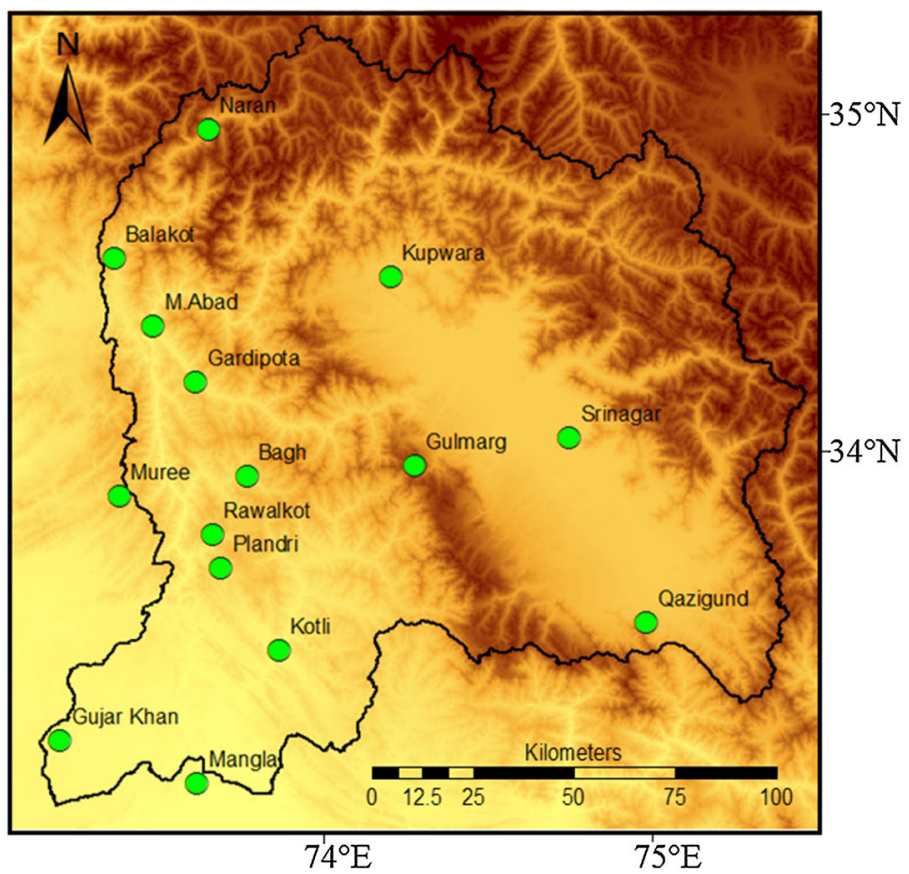

Fig. 1 Location map of Jhelum River Basin and weather stations 
Table 1 Inventory of weather stations used in the present study
Table 2 Description of three selected GCMs used in this study

\begin{tabular}{llllllll}
\hline Sr. no. & Name & Latitude $\left(^{\circ}\right)$ & Longitude $\left(^{\circ}\right)$ & Sr. no. & Name & Latitude $\left(^{\circ}\right)$ & Longitude $\left(^{\circ}\right)$ \\
\hline S1 & Bagh & 33.97 & 73.79 & S9 & Mangla & 33.14 & 73.64 \\
S2 & Balakot & 34.55 & 73.35 & S10 & Murree & 33.91 & 73.38 \\
S3 & Garidhoptta & 34.22 & 73.62 & S11 & Naran & 34.90 & 73.65 \\
S4 & Gujar Khan & 33.26 & 73.30 & S12 & Plandri & 33.72 & 73.71 \\
S5 & Gulmarg & 34.00 & 74.33 & S13 & Qaziqund & 33.58 & 75.08 \\
S6 & Kotli & 33.50 & 73.90 & S14 & Rawalkot & 33.87 & 73.68 \\
S7 & Kupwara & 34.51 & 74.25 & S15 & Srinagar & 34.08 & 74.83 \\
S8 & M.Abad & 34.37 & 73.48 & & & & \\
\hline
\end{tabular}

\begin{tabular}{llllll}
\hline Model name & Short name & Spatial resolution & Modelling countries & Historical period & Future period \\
\hline CanESM2 & CanESM & $2.812^{\circ} \times 2.812^{\circ}$ & Canada & $1961-2005$ & $2006-2100$ \\
MIROC5 & MIROC & $1.406^{\circ} \times 1.406^{\circ}$ & Japan & $1961-2005$ & $2006-2100$ \\
BCC-CSM1-1 & BCC & $2.812^{\circ} \times 2.812^{\circ}$ & China & $1961-2005$ & $2006-2100$ \\
\hline
\end{tabular}

mean sea level pressure and specific humidity) and local observations (i.e., Temperature and Precipitation) and produced some statistical parameters. Weather generator used these regression parameters along with GCM and NCEP predictors and generate few daily time series (consider 25 in this study) that are closely fit with observed data (Saddique et al. 2019).

In SDSM for the selection of most suitable predictors from a set of 26 atmospheric predictors various indictors (correlation matrix, partial correlation, explained variance, scatter plots, $p$ value and histograms) are used for downscaling of precipitation and temperature. Unconditional model was chosen for temperature and a conditional model for precipitation (Wilby and Dawson 2004). As precipitation data is not normally distributed, before its application in the regression analysis a fourth order transformation was applied. Ordinary least square (OLS) method was used for the optimization of model as this method is faster than dual simplex (DS) and produces comparable results (Huang et al. 2011). Figure 2 describes the main steps involved in statistical downscaling method.

The most important step in statistical downscaling methods is screening of predictors during calibration (Huang et al. 2011). In present study correlation coefficient, partial correlation and $p$ value are used for the selection of appropriate predictors. Predictor whose correlation is high selected as a super predictor and other predictors were placed at second and third position based on highest correlation and explained variance.

\subsection{Climate extremes}

The Expert Team (ET) on Climate Change Detection and Indices (ETCCDI) developed a core set of 27 indices to analyze the changes in climate extremes (Peterson 2005). The extreme indices are calculated using the 'Rclimdex' package (Zhang and Yang 2004). For this study 6 precipitation indices and 9 temperature indices were selected to explore the changes in climate extremes of Jhelum River basin (listed in Table 3). To understand how extreme temperature and precipitation changed in the past 30 years and to predict how it will change after 100 years more accurately, we used the observed dataset (1961-1990) and future dataset (2061-2090) to evaluate the climate extremes.

\subsection{Trend analysis}

In the current study, non-parametric Mann-Kendall (MK) test (Mann 1945; Kendall 1975) is employed to determine the trends in the temperature and precipitation extreme indices. MK test is globally applied in hydrological and meteorological studies for detecting trends in time series while Sen's slope estimator determines the magnitude of trend. The MK Z-value $>1.96$ shows significantly increasing trend and $<-1.96$ shows the significantly decreasing trend at $5 \%$ significance level. The null hypothesis $\left(\mathrm{H}_{0}\right)$ for the test signified no trend and the alternate hypothesis suggest that there is increasing or decreasing trend present in the time series. Mathematical Eq. 1 was used to determine the MK trend statistic.

$S=\sum_{i=1}^{m-1} \sum_{j=i+1}^{m} \operatorname{sgn}\left(x_{j}-x_{i}\right)$

pwhere m: the number of observations, $x_{i}$ and $x_{j}$ the $i$ th and jth observations, sgn: the sign function.

sgn is calculated by Eq. 2; 
Fig. 2 Flow chart illustrating the statistical downscaling method

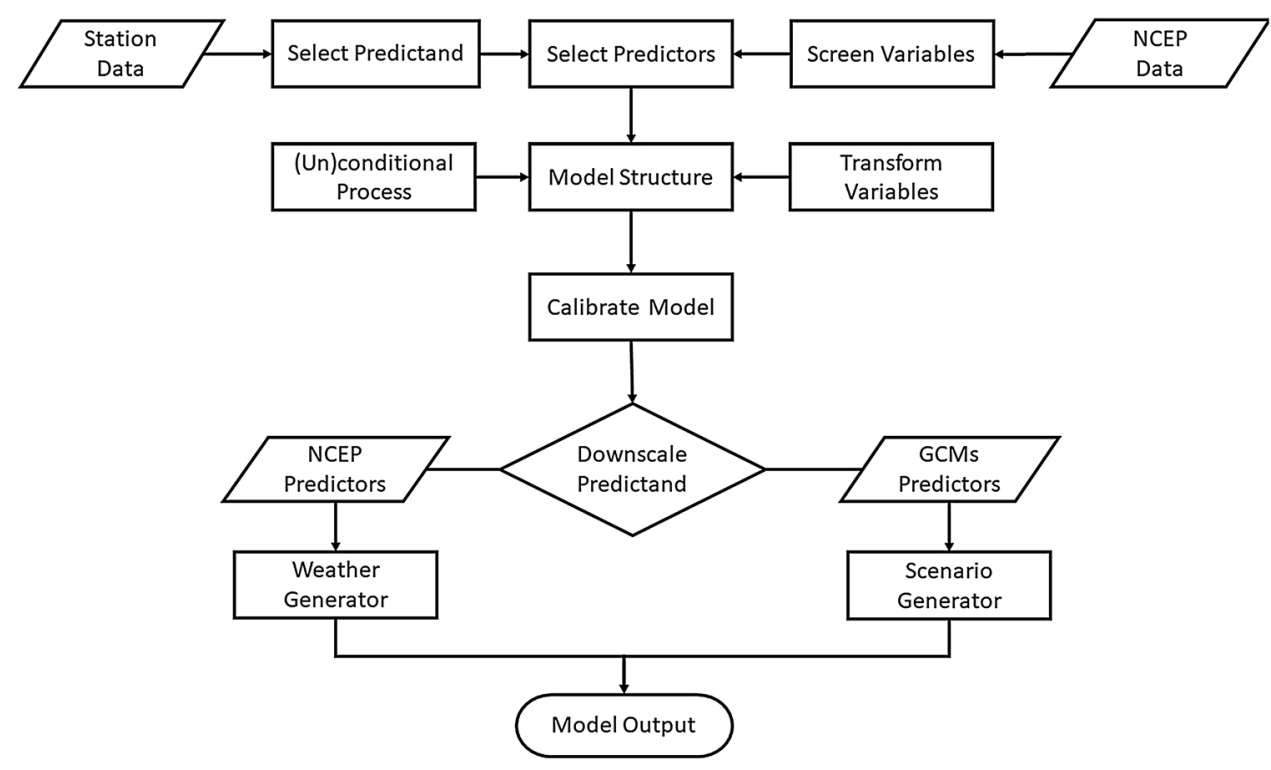

Table 3 List of climate extreme indices used in the present study

\begin{tabular}{lll}
\hline Code & Description & Indices definition \\
\hline Temperature & & \\
TXx & Warmest days & Maximum values of daily maximum temperature \\
TNx & Warmest nights & Maximum values of daily minimum temperature \\
TXn & Coldest days & Minimum values of daily maximum temperature \\
TNn & Coldest nights & Minimum values of daily minimum temperature \\
TX90p & Warm days & Percentage of days in a year when daily maximum temperature $>90$ th percentile \\
TN90p & Warm nights & Percentage of nights in a year when daily min temperature $>90$ th percentile \\
TX10p & Cold days & Percentage of days in a year when daily maximum temperature $<10$ th percentile \\
TN10p & Cold nights & Percentage of nights in a year when daily min temperature $<10$ th percentile \\
SU & Summer days & Annual number of days when daily maximum temperature $>25{ }^{\circ} \mathrm{C}$ \\
Precipitation & & \\
RX1 day & Max 1-day precipitation amount & Annual maximum 1 day precipitation \\
RX5 day & Max 5-day precipitation amount & Annual maximum consecutive 5 day precipitation \\
R95p & Very wet days & Total annual precipitation from days $>95$ th percentile \\
SDII & Simple daily intensity index & The ratio of annual total wet-day precipitation to the number of wet days \\
PRCPTOT & Annual total wet-day precipitation & Total annual precipitation from days $\geq 1$ mm \\
R10mm & Number of heavy precipitation days & Count the number of days where rainfall $\geq 10$ mm \\
\hline
\end{tabular}

$\operatorname{sgn}\left(x_{j}-x_{i}\right)=\left\{\begin{array}{cl}1 & \text { if }\left(x_{j}-x_{i}\right)>0 \\ 0 & \text { if }\left(x_{j}-x_{i}\right)=0 \\ -1 & \text { if }\left(x_{j}-x_{i}\right)<1\end{array}\right.$

The $S$ statistic mean and variance are calculated as (Eqs. 3 and 4, respectively);

$E(S)=0$
$\operatorname{Var}(S)=\frac{m(m-1)(2 m+5)-\sum_{p=1}^{q} t_{p}\left(t_{p}-1\right)\left(2 t_{p}+5\right)}{18}$

where q: the number of tied groups, $t_{p}$ : the number of observations in pth group.

The MK Z statistic is calculated by (Eq. 5); 
$Z=\left\{\begin{array}{cc}\frac{S-1}{\operatorname{Var}(S)} & \text { for } S>0 \\ 0 & \text { for } S=0 \\ \frac{S+1}{\operatorname{Var}(S)} & \text { for } S<0\end{array}\right.$

\section{Results and discussion}

\subsection{Observed extremes indices}

\subsubsection{Observed (historical) temperature indices}

The 1961-1990 extreme observed (historical) temperature trends showed (Fig. 3) that the intensity and frequency of temperature extremes significantly increase, while the intensity and frequency of cold temperature extremes significantly decrease. Statistically, warming trends are observed at 0.05 significance level at most of the stations of Jhelum River basin. Compared to, warmest days (TXx) and warmest nights (TNx), the coldest days (TXn) and coldest nights (TNn) have more increasing trends with magnitude 1.13 and $1.32{ }^{\circ} \mathrm{C}$ per decade.

In case of TXn and TNn about $90 \%$ stations are featured by significant positive trends at $5 \%$ significance level while for TXx and TNx about 25\% stations showed significant results. The results of prior studies by Mahmood and Babel (2014) also illustrated an upward trend (positive) in these indices.

The frequency indices (for instance- warm days (TX90p), cold days (TX10p), warm nights (TN90p), and cold nights (TN10p) are presented in Fig. 4. Generally, TX10p and TN10p show significantly decreasing trends with magnitude of $-1.30 \%$ and $-1.17 \%$ per decade respectively $(-4.74$ and -4.01 days per decade) while the TX90p and TN90p revealed significantly increasing trends with a mean rate of 3.6 and 2 days per decade respectively. Figure $4 \mathrm{~b}, \mathrm{~d}$ showed that nearly all the stations exhibit a decreasing trend in cold days and nights, and approximately $90 \%$ of these stations have significant trends at the 0.05 level. In general, more than $95 \%$ of the stations showed increasing trend in warm days and nights at $95 \%$ confidence interval (Fig. 4a, c). The Fifth Assessment
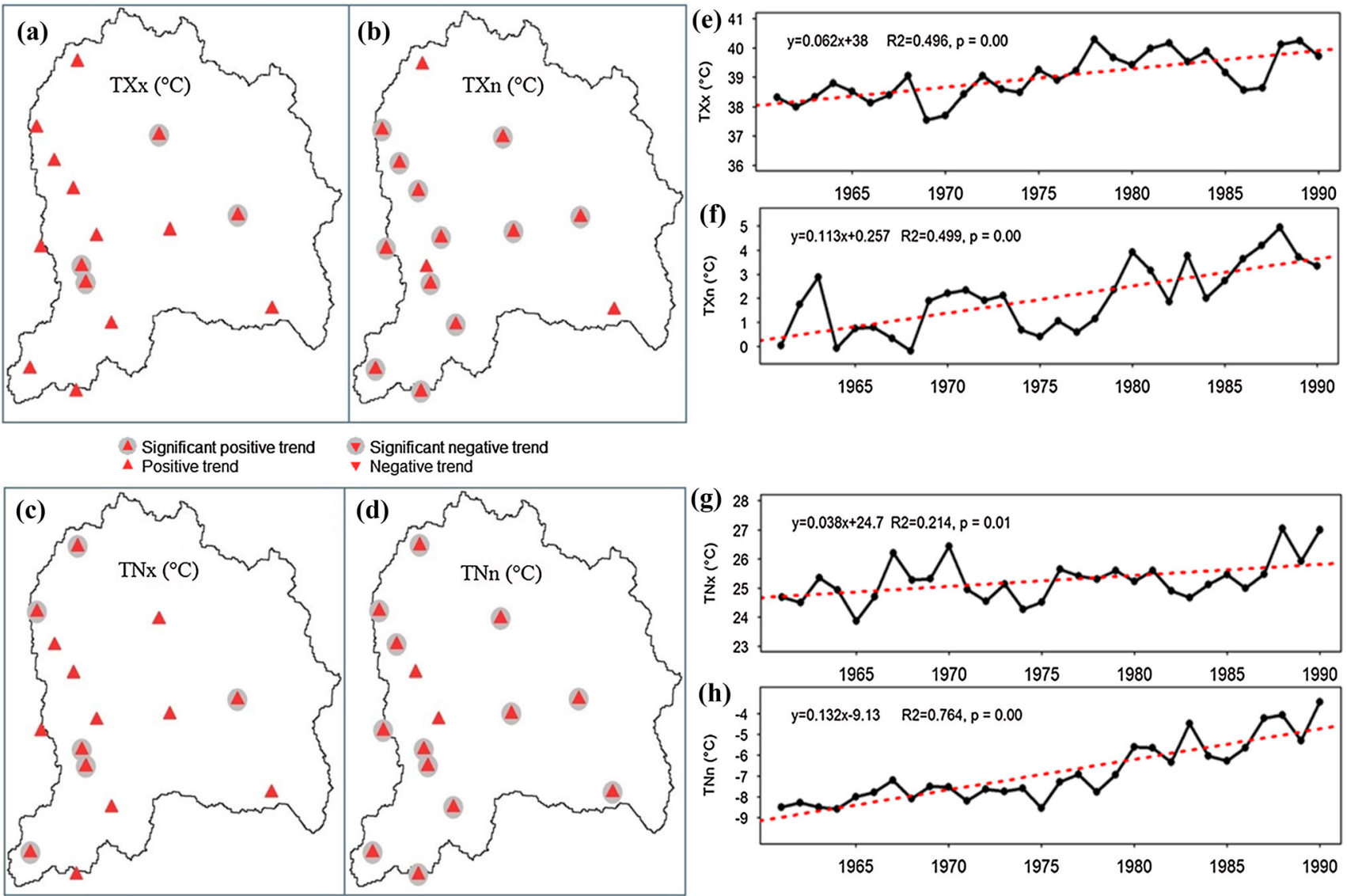

Fig. 3 Station trends (left) for a warmest day, b coldest day, c warmest night, $\mathbf{d}$ coldest night- positive trends are represented by upward triangles, negative trends by downward triangles and significant trends by gray circles; regional series (right) for e warmest days, $\mathbf{f}$ coldest days, $\mathbf{g}$ warmest nights, $\mathbf{h}$ coldest nights for the period of 1961-1990 

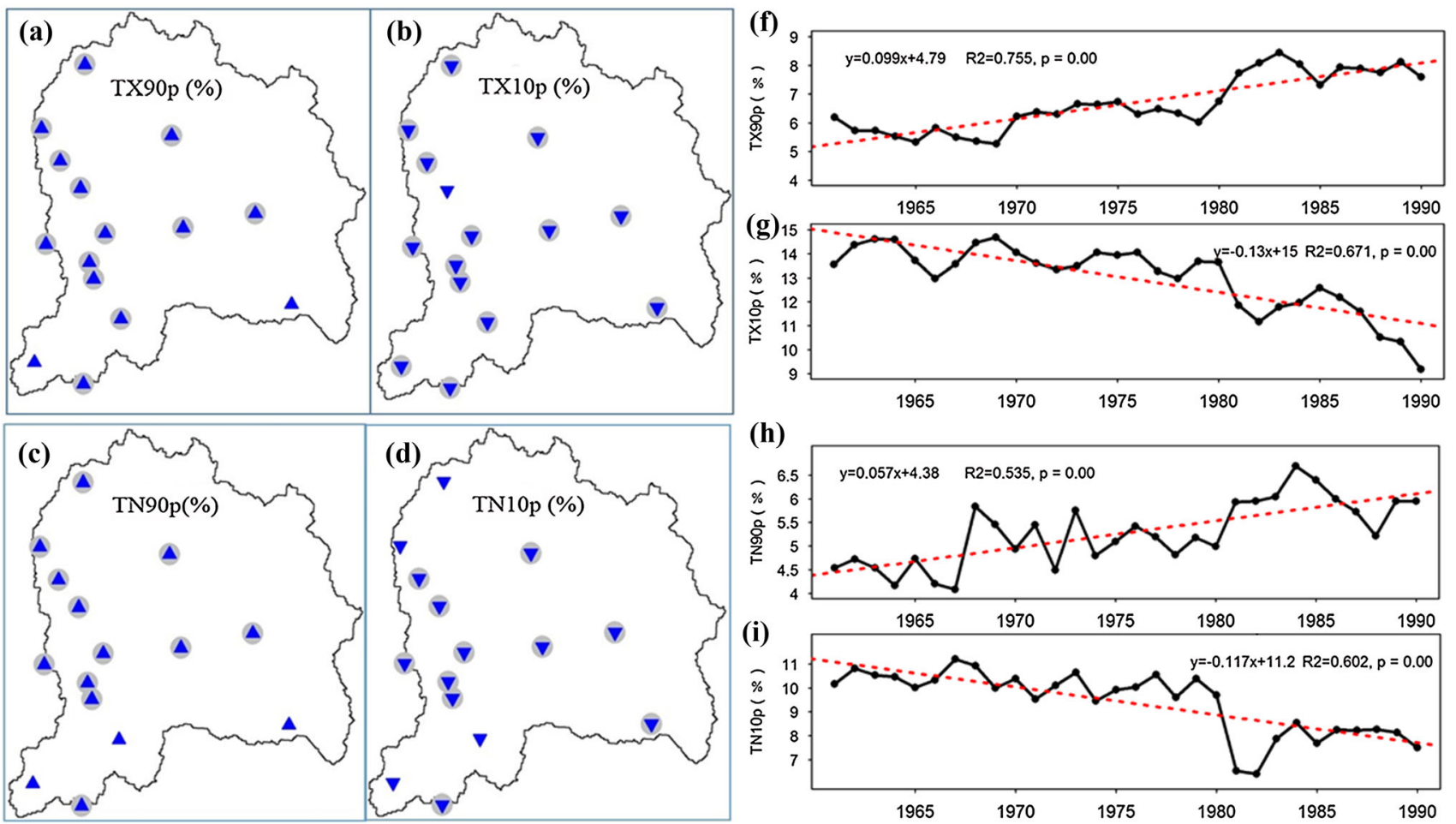

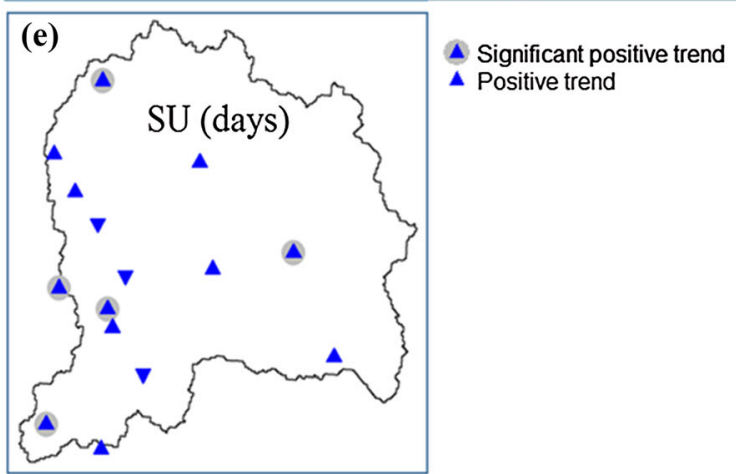

Fig. 4 Station trends (left) for percentage of a warm days, b cold days, $\mathbf{c}$ warm nights, $\mathbf{d}$ cold nights and $\mathbf{e}$ number of summer dayspositive trends are indicated by upward triangles, negative trends by

Report (AR5) of the IPCC has also been presented similar conclusions for most land areas in the world (IPCC 2013). In general, the number of summer days (SU) increased over the study area as shown in Figure $4 \mathrm{j}$, the mean increase in SU was 4.47 days per decade over the study basin. It can be seen that three stations (Kotli, Bagh, and Garidhoptta) showed decreasing trends in summer days while the other stations presented increasing trends (Fig. 4e).

\subsubsection{Observed (historical) precipitation indices}

The maximum 1-day precipitation amount (RX1) exhibited (Fig. $5 \mathrm{~g}$ ) significantly increasing trend with a magnitude of $0.85 \mathrm{~mm} /$ year. The basin average RX1-day varied between 77.89 and $134.64 \mathrm{~mm}$ for the baseline period 1961-1990. downward triangles and significant trends by gray circles; regional series (right) of $\mathbf{f}$ warm days, $\mathbf{g}$ cold days, $\mathbf{h}$ warm nights, $\mathbf{i}$ cold nights and $\mathbf{j}$ summer days for the period of 1961-1990

All the 15 stations of basin showed upward (increasing) trend of RX1-day, four stations have significant positive trends (Fig. 5a). Similarly, maximum 5-day precipitation amount represents increasing trend with magnitude 1.38 $\mathrm{mm}$ per year for the study area (Fig. $5 \mathrm{~h}$ ). Most of the stations showed increasing trend except Rawalkot and Garidhoptta. The RX5-day series ranged between 118.87 $\mathrm{mm}$ to $236.47 \mathrm{~mm}$ during the different years of baseline period. It can be seen from Fig. $5 \mathrm{i}$ that the annual total wet day precipitation (PRCPTOT) substantially increased by $5.72 \mathrm{~mm} /$ year. All the stations showed increasing trends in PRCPTOT (Fig. 5c). Murree, Muzaffarabad, and Qaziqund revealed significant positive trends at 0.05 significance level. Overall, if the rain intensity increases then frequency 

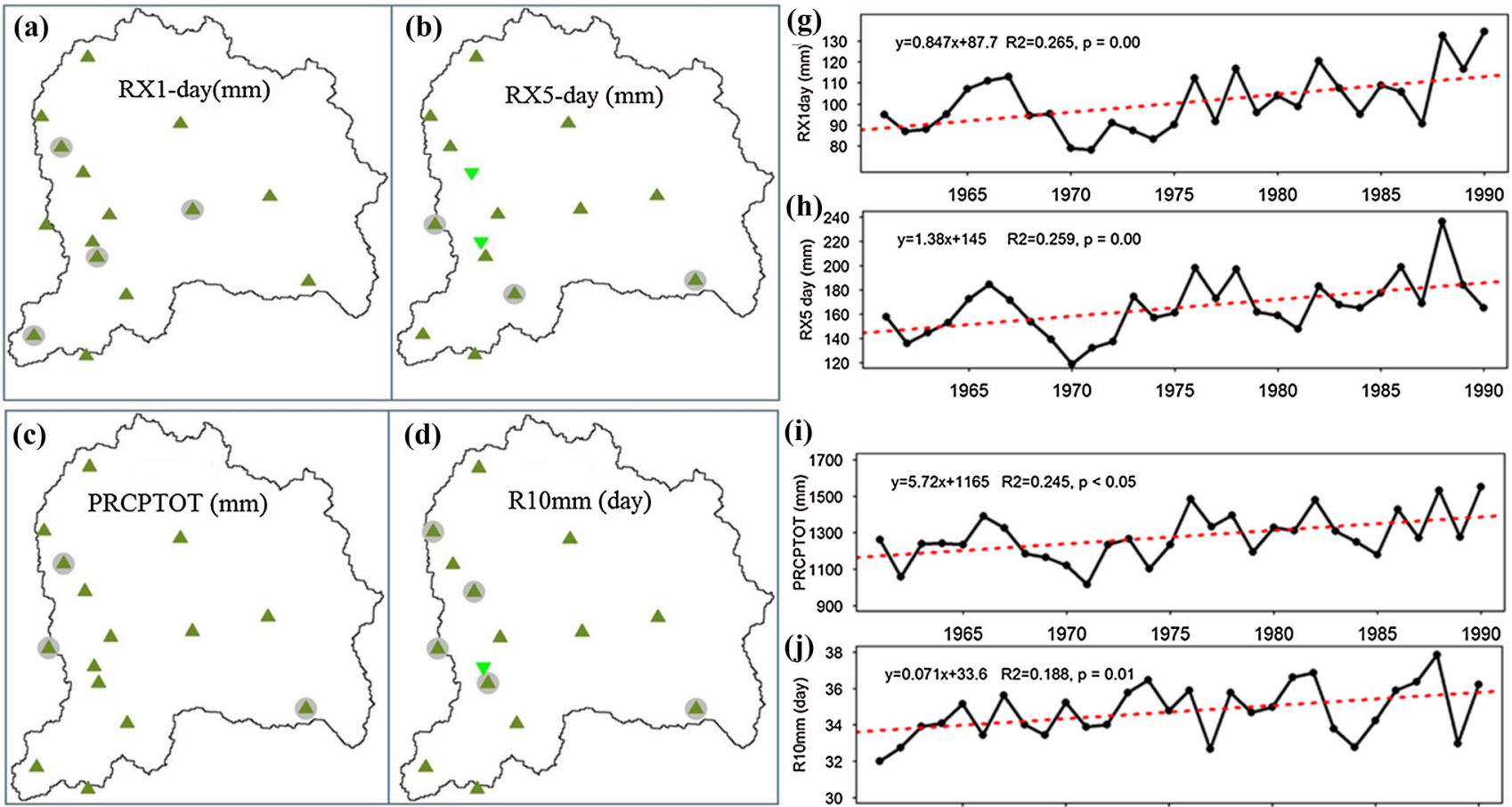

(i)
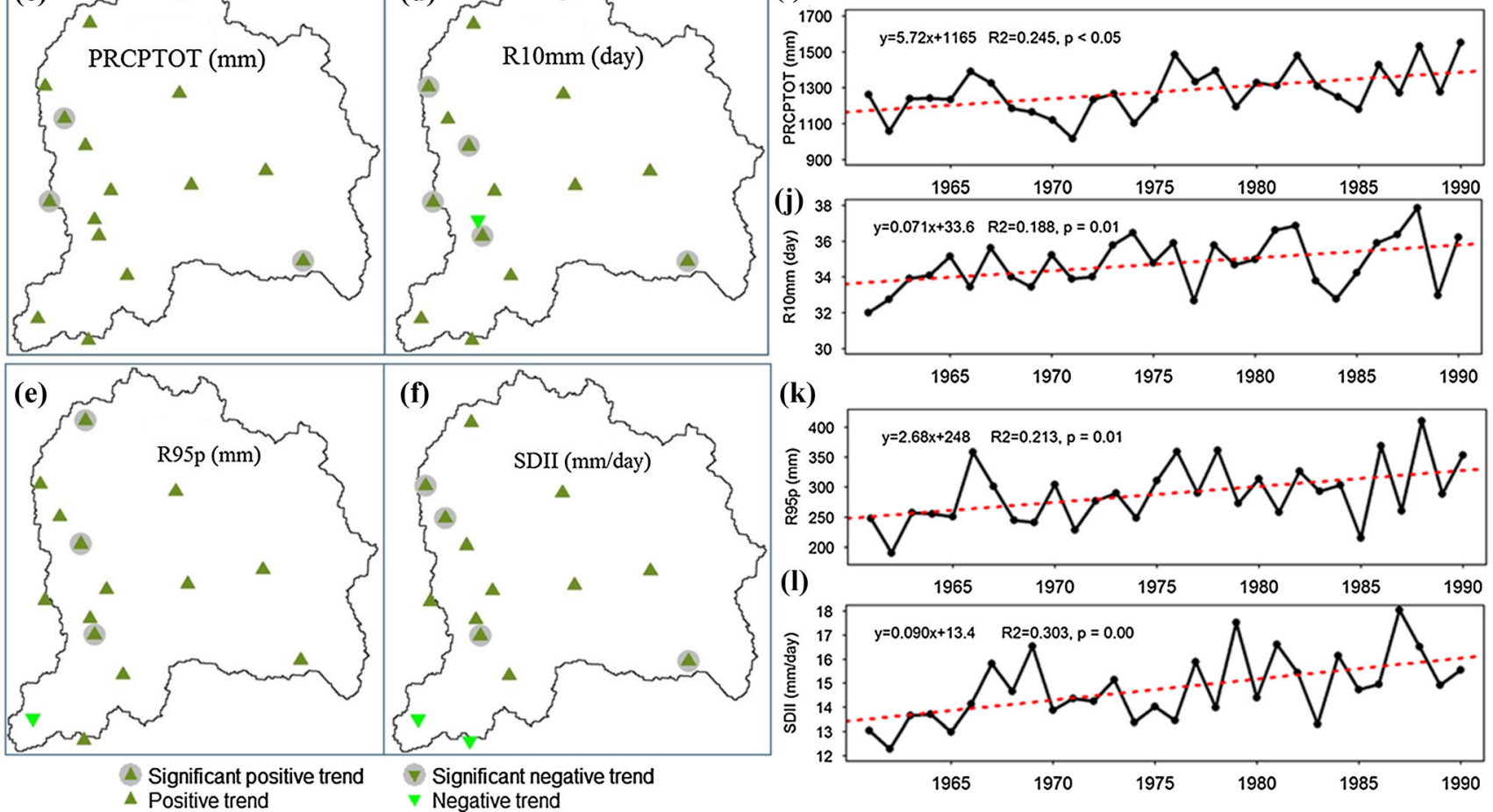

Fig. 5 Station trend (left) for a RX1-day, b RX5-day, c PRCPTOT, d R10mm, e R95p, f SDII; regional time series (right) for $\mathbf{g}$ RX1-day, h RX5-day, i PRCPTOT, $\mathbf{j}$ R10mm, k R95p, I SDII for the period of 1961-1990

of wet days was expected to decrease during the year (Casanueva Vicente et al. 2014).

The number of heavy precipitation days (R10 mm) ranged between 32.00 and 37.87 days in different years of baseline period. The number of heavy precipitation days showed significant positive trends at the $95 \%$ confidence interval at Murree, Balakot, Garidhoptta, Plandri, and Qaziqund, with an increase of 1.40, 0.75, 0.45, 0.85 and 1.14 days per decade, respectively. Only one station (Rawalkot) showed decreasing trend at the rate of -1.1 days per decade (Fig. 5d). For the whole Jhelum River basin average increase in R10 about 0.71 days per decade (Fig. 5j). The simple daily intensity index (SDII) increased with annual trend of $0.09 \mathrm{~mm} /$ day/year. The basin average SDII ranged between $12.26 \mathrm{~mm} /$ day to $18.0 \mathrm{~mm}$ /day for the observed period. All the stations exhibited positive trends except Mangla and Gujar khan. The results of this study are consistent with the findings of Hartmann and Buchanan (2014) who analyzed the precipitation data for period the period 1979-2011 and found increasing trends in precipitation extremes indices in Indus Basin.

\subsection{Projected precipitation and temperature extremes indices}

Future climate indices over the Jhelum River basin are calculated using the ensemble of three GCMs under two RCPs scenarios (RCP4.5 and RCP8.5) for one-time slice (2061-2090). 


\subsubsection{Temperature indices under RCP4.5 and RCP8.5}

Figure 6 represents the temperature indices for projected climate. The results show that average annual indices expected to be higher in future period (2061-2090) than those in baseline period (1961-1990). TX90p and TN90p expected to increase drastically under both emission scenarios (Fig. 6a, b). The Basin average TX90p increased by $8.89 \%$ under RCP4.5 and $14.43 \%$ under RCP8.5 after 100 years of observed period. TN90p also shows a consistent increase of $10.83 \%$ and $18.09 \%$ for RCP4.5 and RCP8.5 respectively. On the other hand, TX10p and TN10p expected to decrease for projected climate over the Jhelum River basin. It can be seen that cool days and nights decreased more drastically under RCP8.5 (high emission scenario) as compared to RCP 4.5 (Fig. 6c, d). Garidhoptta (S3) and Gujar Khan (S4) exhibited slightly increase in TX10p for RCP 4.5. We found that TXx, TXn, TNx, and TNn also increased for the projected climate. Maximum value of daily maximum temperature (TXx) and minimum temperature (TNx) rise by 1.22 and $1.35^{\circ} \mathrm{C}$ under RCP4.5; similar findings are found under RCPs 8.5 but with higher magnitude $\left(2.16\right.$ and $1.93{ }^{\circ} \mathrm{C}$ ). TXn (minimum value of daily maximum temperature) and TNn (minimum values of daily minimum temperature) show slightly high-rise in values under RCP8.5 as compared to TXx and TNx. There was an increase of summer days (SU) for all the stations of basin. Three stations (Gulmarg S5, Murree S10, and Naran S11) of basin have very few summer days as these stations lie at high altitudes (Fig. 6i). Islam et al. (2009) projected an increasing trend in warm spell while decreasing trend in cold spell using RCM PRECIS for the period 2071-2100 over Pakistan. They also found that increase in minimum temperature was more as compared to maximum temperature. Mahmood and Babel (2014) also reported a large increase in temperature extremes in the study area. For instance, coldest nights $(\mathrm{TNn})$ were found to increase by $4.7{ }^{\circ} \mathrm{C}$ in winter whereas hot days (TX90P) and hot nights (TN90P) were found to increase by 2.09 and $1.46{ }^{\circ} \mathrm{C}$ in spring at the end of this century.

\subsubsection{Precipitation indices under RCP4.5 and RCP8.5}

Figure 7 illustrates projected climate mean precipitation indices for 30-year (2061-2090) at all the stations. We observed an increase in precipitation for more than $90 \%$ stations, the precipitation indices were also anticipated to increase. Generally, majority of the indices revealed increase from RCP4.5 to RCP8.5. RX1-day increased about $13.29 \mathrm{~mm}$ under RCP4.5 and about $17.39 \mathrm{~mm}$ under RCP8.5 relative to baseline (1961-1990). All the stations (Fig. 7a) of JRB showed increase in RX1-day under both RCPs scenarios except Garidhoptta (S3). Similarly, it can be seen that RX5-day also increase by $15.40 \mathrm{~mm}$ and 26.77 mm under both RCPs (Fig. 7b). Projected climate show increase in number of heavy precipitation days $(\mathrm{R} 10 \mathrm{~mm})$ when compared with referenced period for most of the stations (Fig. 7c). We found basin average increase of 1.57 days for RCP4.5 and 3.15 days for RCP8.5. A consistent increase in SDII values for all the stations with both scenarios (Fig. 7d). Comparing to referenced climate, SDII increased by $1.51 \mathrm{~mm} /$ day and $3.25 \mathrm{~mm} /$ day under medium and high emission scenarios, respectively. It is seen that PRCPTOT also increased under both emission scenarios for all the stations except Kupwara (S7). Figure 7f showed that R95p (very wet days) increase under both scenarios but some stations (Bagh, Balakot, Garidhoptta, and Murree) have drastic increase. Under RCP 4.5, R95p increased by $75.30 \mathrm{~mm}$ and $94.16 \mathrm{~mm}$ under RCP8.5. Sharma and Goyal (2020) projected an increase in precipitation indices such as R10 mm, R95p, RX1-day and RX5-day in Eastern Himalayas using four GCMs under two RCPs scenarios for the period of 1950-2100.

\subsubsection{Trends analysis of projected climate under RCP4.5}

Table 4 shows the temperature and precipitation indices trend analysis for the future period (2061-2090) under RCP4.5. The frequency of TX90p and TN90p are expected to increase across the whole basin. In this regard, all the stations showed significant positive trend, with a highest increase of $3.79 \%$ (13.83 days) per decade. On the other hand, frequency of TX10p and TN10p exhibits a decreasing trend. In case of TN10p Gulmarg, Mangla, Rawalkot, and Sarinagr showed significant decreasing trend. All the stations revealed positive trends in TXx, TXn, TNx, and TNn. TXx exhibited significant positive trend for all the stations except Plandri (non-significant positive). We found highest increase in maximum value of daily minimum temperature (TNx) as compared to other three indices. Number SU showed significant positive trends at most of the stations except Gulmarg, Naran, and Plandri with a highest trend of 3.89 days per decade.

In general, all precipitation indices showed positive trends at most of the stations. RX1-day and RX5-day indices had all positive trend except for the negative trend at Garidhoptta, M. Abad, Gujar Khan, and Naran stations. However, these negative trends are not significant. In case of PRCPTOT, having the highest value of $39.71 \mathrm{~mm}$ per decade except for Murree and Naran with negative trends of -9.31 and $-11.31 \mathrm{~mm} /$ decade. R10 $\mathrm{mm}$ and SDII also showed positive trends for most of the climate stations for future time slice. R95p (very wet days) are observed to have positive trend in 2061-2090 with highest trend of $44.20 \mathrm{~mm}$ per decade. The positive trends in R95p are significant at Balakot, Kupwara, and Plandri. 
Fig. 6 Comparison of annual average extreme indices of temperature for the projected climate (2061-2090) and for the observed period (1961-1990) at all the stations of Jhelum River basin
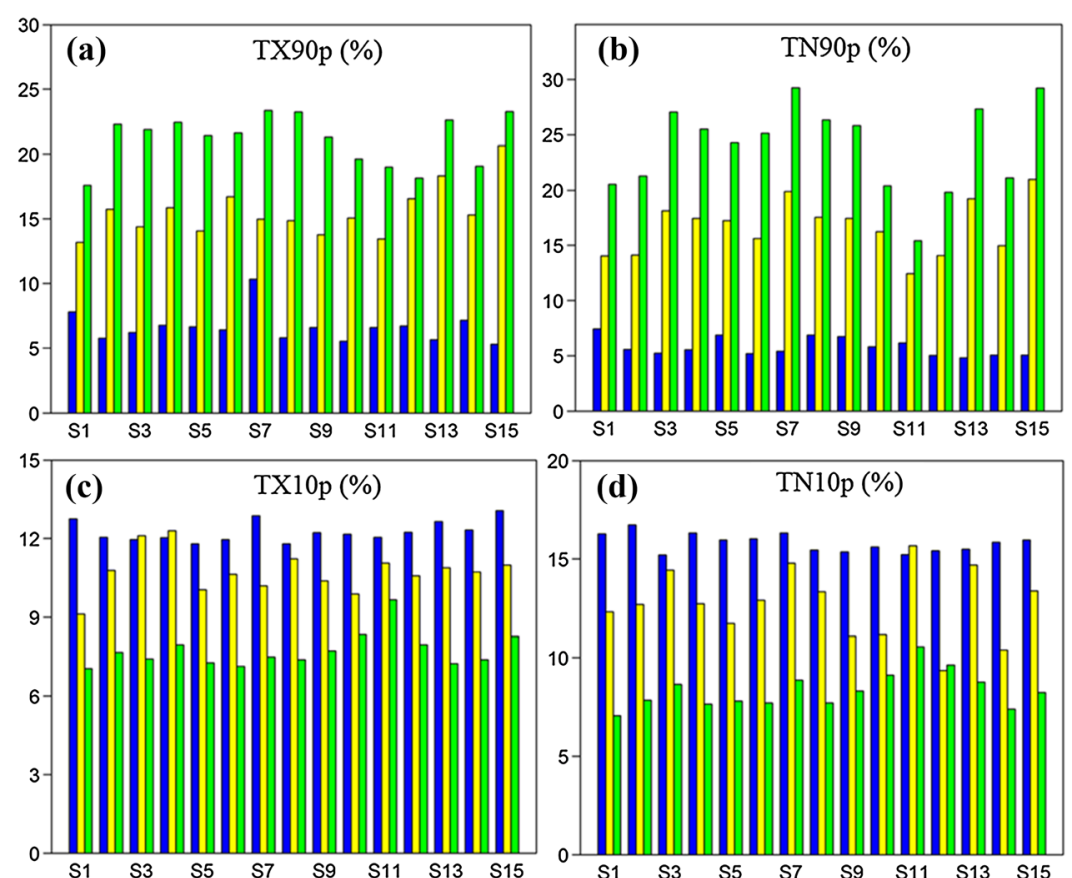

(d)
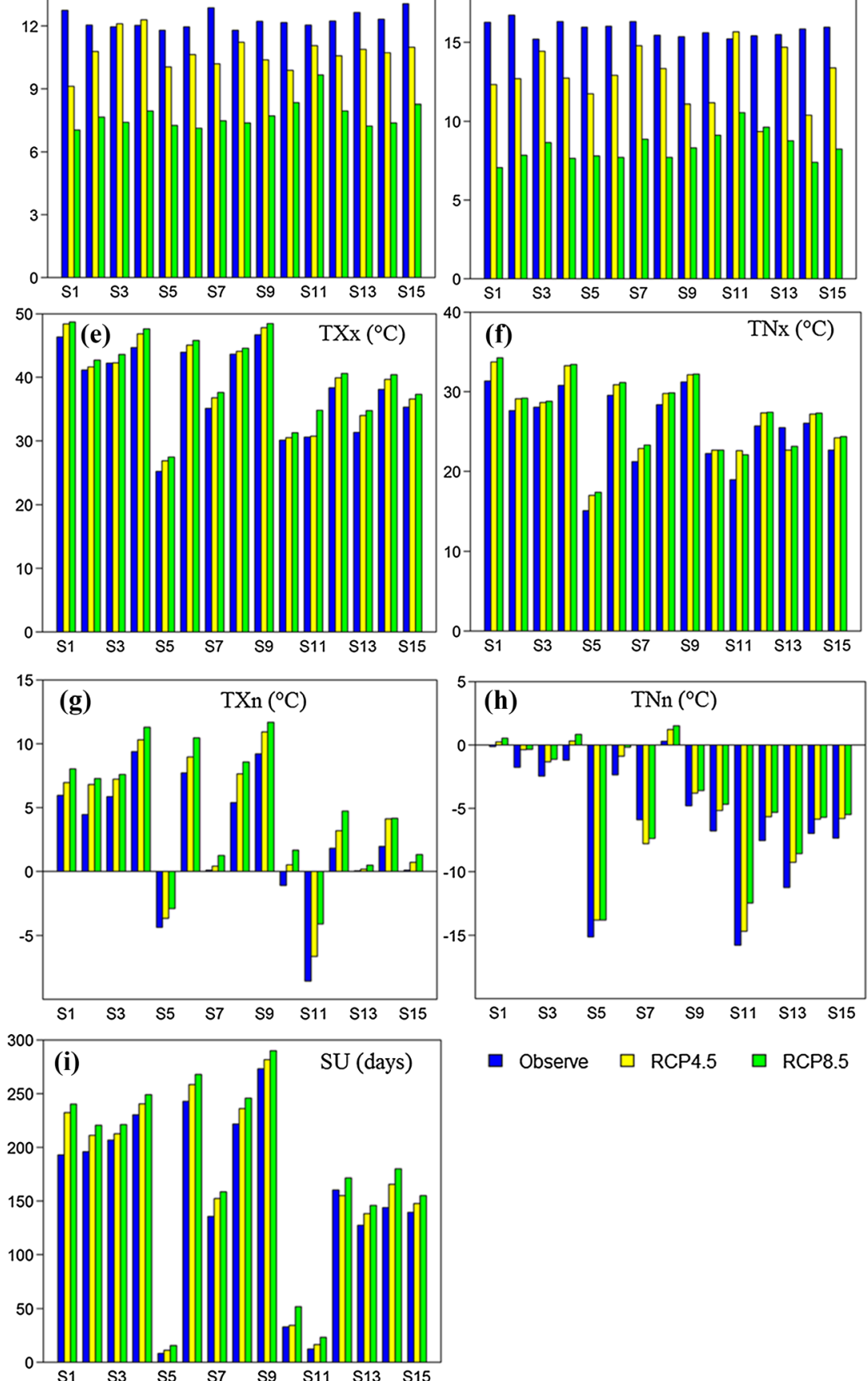

- Observe

$\square$ RCP 4.5

口 RCP8.5 
Fig. 7 Comparison of annual average extreme indices of precipitation for the projected climate (2061-2090) and for the observed period (1961-1990) at all the stations of Jhelum River basin
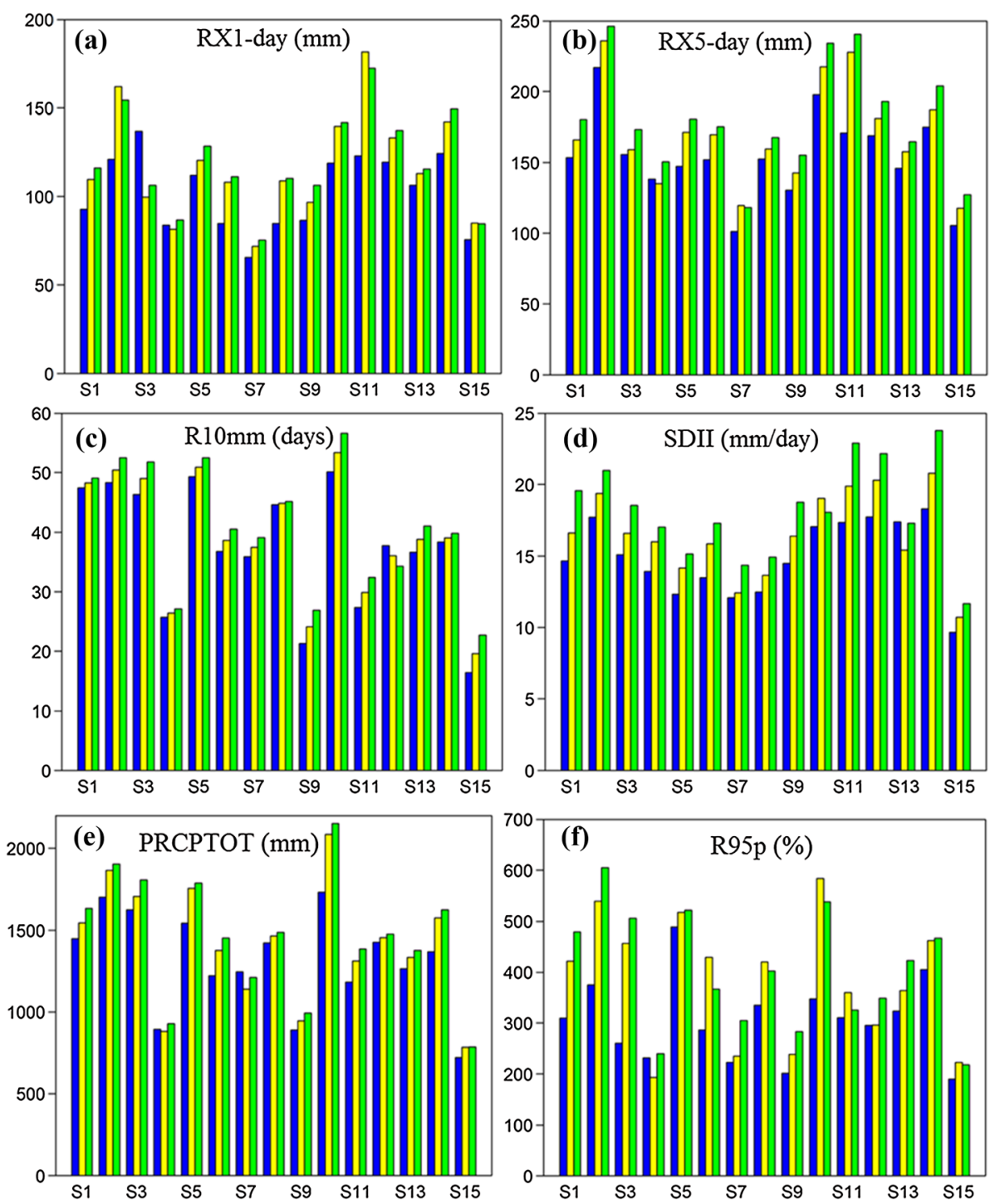

\subsubsection{Trends analysis of projected climate under RCP8.5}

Table 5 illustrates significant positive trends in number of warm days and number of warm nights for all stations except Garidhoptta, Naran, Murree, and Qaziqund while all stations exhibited decreasing trends in frequency of cool nights and cool days. Positive trends in frequency of warm days and nights (1.96-4.89\% per decade) are seen at Jhelum river basin while the negative trend in frequency of cool days and nights $(-1.18$ to $-2.89 \%$ per decade) is observed at study area. TXx, TNx, TXn, and TNn exhibited positive trends at all stations like RCP 4.5 but with higher magnitudes. In case of minimum value of daily minimum temperature, all stations showed significant positive trends except Qaziqund. Results of future analysis show that positive trends in TXx, TXn, TNX, and TNn ranged between 0.23 and $0.96{ }^{\circ} \mathrm{C}$ per decade. There was a broad increasing trend in summer days, especially for the Qaziqund that showed an increase of 6.67 days per decade.

All the precipitation indices showed positive trends under RCP8.5 except for RX1 and RX5 with few stations negative trends. The highest positive trend of $58.92 \mathrm{~mm}$ per decade was reported in annual total precipitation at Garidhoptta. For the future time, slice RX1-day and RX5day rainfall exhibited positive trends except for negative trends at Gujar khan, Mangla, and M. Abad. In case of RX5-day highest positive trend of $13.12 \mathrm{~mm}$ was recorded at Garidhoptta. Heavy precipitation days had significant positive trends at Garidhoptta, Mangla, and Rawalkot and rainfall intensity index had significant positive trends at Balakot, Garidhoptta, Mangla and Qaziqund. Regarding the very wet days (R95p), four stations revealed significant positive trends; highest magnitude of $51.34 \mathrm{~mm}$ per decade was found at Bagh. Different studies carried out in Indus Basin have also reported an increase in temperature and 
Table 4 Decadal trends of GCMs ensemble means extremes Indices under RCP4.5 during 2061-2090

\begin{tabular}{|c|c|c|c|c|c|c|c|c|c|c|c|c|c|c|c|}
\hline \multirow[t]{2}{*}{ Stations } & \multicolumn{9}{|c|}{ Temperature indices } & \multicolumn{6}{|c|}{ Precipitation indices } \\
\hline & TXx & TXn & TNx & $\mathrm{TNn}$ & TX90p & Tx10p & TN90p & TN10p & SU & $\mathrm{PRCP}$ & $\mathrm{RX} 1$ & RX5 & $\mathrm{R} 10$ & SDII & R90p \\
\hline Bagh & 0.19 & 0.20 & 0.60 & 0.38 & 1.38 & -1.47 & 2.09 & -1.22 & 2.86 & 19.21 & 4.00 & 4.74 & -0.21 & 0.23 & 42.20 \\
\hline Balakot & 0.26 & 0.30 & 0.60 & 0.41 & 2.24 & -1.30 & 2.48 & -1.56 & 2.58 & 26.11 & 5.21 & 11.18 & 0.43 & 0.44 & 44.20 \\
\hline Garidoptta & 0.22 & 0.23 & 0.53 & 0.35 & 2.51 & -1.11 & 2.79 & -1.89 & 2.86 & 39.71 & -0.28 & 1.50 & 0.40 & 0.36 & 24.00 \\
\hline Gujar khan & 0.31 & 0.35 & 0.53 & 0.50 & 2.54 & -1.13 & 3.49 & -1.25 & 1.94 & 9.8 & 1.17 & -1.82 & 0.60 & -0.07 & 1.41 \\
\hline Gulmarg & 0.29 & 0.21 & 0.50 & 0.45 & 1.99 & -1.10 & 2.80 & -2.17 & 2.78 & 23.98 & 5.53 & 7.35 & 0.56 & 0.29 & 26.08 \\
\hline Kotli & $\mathbf{0 . 3 7}$ & 0.20 & 0.52 & 0.52 & 2.74 & -1.45 & 2.56 & -1.45 & 2.50 & 8.09 & 2.40 & 1.83 & 0.74 & 0.19 & 26.30 \\
\hline Kupwara & 0.19 & 0.31 & 0.62 & 0.42 & 2.39 & -2.14 & 3.79 & -1.29 & 2.78 & 22.34 & 3.33 & 3.42 & 0.43 & 0.08 & 18.53 \\
\hline M.Abad & 0.26 & 0.19 & 0.40 & 0.36 & 2.58 & -1.17 & 2.75 & -1.54 & 2.63 & 20.74 & -1.08 & 0.28 & 0.49 & 0.20 & 23.59 \\
\hline Mangla & 0.25 & 0.31 & 0.45 & 0.23 & 1.54 & -2.27 & 3.18 & -2.67 & 2.38 & 14.21 & 1.32 & 1.44 & 0.87 & 0.24 & 5.81 \\
\hline Murree & 0.41 & 0.33 & 0.54 & 0.36 & 2.74 & -1.80 & 2.74 & -2.45 & 1.35 & -9.31 & 0.97 & 0.83 & 0.25 & 0.33 & 26.97 \\
\hline Naran & 0.18 & 0.35 & 0.45 & 0.45 & 1.75 & -1.22 & 1.52 & -1.25 & 1.16 & -11.31 & 0.15 & -0.31 & 0.13 & 0.17 & 28.14 \\
\hline Plandri & 0.20 & 0.36 & 0.46 & 0.34 & 2.84 & -1.15 & 2.45 & -1.85 & 1.10 & 31.45 & 0.27 & 5.17 & 0.93 & 0.12 & 20.27 \\
\hline Qaziqund & 0.33 & 0.15 & 0.53 & 0.46 & 1.34 & -2.21 & 2.97 & -1.16 & 3.33 & 34.45 & 4.28 & 8.92 & 0.67 & 0.54 & 36.04 \\
\hline Rawalkot & 0.45 & 0.25 & 0.40 & 0.51 & 2.12 & -1.58 & 2.09 & -1.65 & 3.89 & 28.90 & 2.57 & 3.98 & 0.21 & 0.53 & 9.63 \\
\hline Sarinagr & 0.28 & 0.25 & 0.56 & 0.41 & 2.34 & -1.12 & 3.04 & -1.27 & 2.37 & 13.45 & 2.87 & 5.79 & 0.11 & 0.29 & 12.63 \\
\hline
\end{tabular}

Bold values represent significant trends at $95 \%$ confidence interval

Table 5 Decadal trends of GCMs ensemble means extremes Indices under RCP8.5 during 2061-2090

\begin{tabular}{|c|c|c|c|c|c|c|c|c|c|c|c|c|c|c|c|}
\hline \multirow[t]{2}{*}{ Stations } & \multicolumn{9}{|c|}{ Temperature indices } & \multicolumn{6}{|c|}{ Precipitation indices } \\
\hline & TXx & TXn & $\mathrm{TNx}$ & TNn & TX90p & Tx10p & TN90p & TN10p & SU & PRCP & $\mathrm{RX} 1$ & $\mathrm{RX} 5$ & $\mathrm{R} 10$ & SDII & R90p \\
\hline Bagh & 0.63 & 0.24 & 0.72 & 0.88 & 1.96 & -1.96 & 2.58 & -2.89 & 3.24 & 42.61 & 4.30 & 5.45 & 0.26 & 0.43 & 51.34 \\
\hline Balakot & 0.27 & 0.60 & 0.51 & 0.52 & 2.91 & -1.58 & 2.63 & -1.78 & 3.25 & 44.53 & 6.27 & 13.12 & 0.47 & 0.55 & 47.98 \\
\hline Garidoptta & 0.32 & 0.43 & 0.75 & 0.35 & 3.38 & -1.64 & 3.87 & -2.1 & 3.89 & 58.92 & 1.83 & 2.23 & 0.55 & 0.58 & 15.67 \\
\hline Gujar khan & 0.42 & 0.41 & 0.65 & 0.36 & 3.58 & -1.63 & 2.96 & -1.54 & 2.18 & 15.86 & -2.82 & 2.92 & 0.32 & 0.16 & 8.54 \\
\hline Gulmarg & 0.60 & 0.25 & 0.52 & 0.28 & 3.85 & -2.01 & 4.41 & -2.79 & 2.57 & 35.85 & 5.17 & 8.94 & 0.75 & 0.35 & 32.76 \\
\hline Kotli & 0.42 & 0.29 & 0.45 & 0.25 & 2.48 & -1.89 & 2.85 & -1.46 & 3.67 & 37.76 & 4.80 & 2.33 & 0.83 & 0.28 & 37.28 \\
\hline Kupwara & 0.29 & 0.39 & 0.54 & 0.52 & 3.40 & -1.55 & 2.98 & -2.01 & 5.33 & 30.31 & 5.33 & 4.48 & 0.49 & 0.13 & 24.54 \\
\hline M.Abad & 0.31 & 0.88 & 0.61 & 0.48 & 3.48 & -2.83 & 4.85 & -1.60 & 3.33 & 36.56 & 2.79 & -1.13 & 0.61 & 0.24 & 28.33 \\
\hline Mangla & 0.38 & 0.28 & 0.42 & 0.32 & 3.85 & -1.30 & 3.20 & -1.55 & 3.75 & 20.54 & -2.45 & 2.75 & 0.72 & 0.47 & 24.12 \\
\hline Murree & 0.53 & 0.67 & 0.96 & 0.56 & 3.23 & -1.73 & 4.11 & -1.34 & 3.67 & 7.50 & 3.18 & 1.75 & 0.27 & 0.49 & 32.27 \\
\hline Naran & 0.31 & 0.38 & 0.67 & 0.41 & 2.74 & -1.35 & 2.74 & -1.65 & 2.13 & 4.46 & 1.15 & 6.73 & 0.34 & 0.18 & 29.32 \\
\hline Plandri & 0.38 & 0.90 & 0.73 & 0.35 & 3.40 & -1.37 & 2.56 & -1.96 & 2.00 & 29.46 & 3.85 & 5.71 & 0.96 & 0.17 & 39.58 \\
\hline Qaziqund & 0.50 & 0.23 & 0.58 & 0.54 & 2.20 & -2.64 & 2.52 & -1.18 & 6.67 & 45.81 & 4.04 & 10.23 & 0.53 & 0.52 & 32.10 \\
\hline Rawalkot & 0.62 & 0.31 & 0.54 & 0.70 & 2.52 & -1.23 & 4.27 & -2.2 & 2.50 & 31.20 & 4.36 & 4.23 & 0.39 & 0.65 & 14.60 \\
\hline Sarinagr & 0.34 & 0.83 & 0.46 & 0.73 & 3.04 & -1.54 & 4.89 & -2.67 & 5.00 & 16.34 & 3.06 & 5.92 & 0.23 & 0.17 & 21.34 \\
\hline
\end{tabular}

Bold values represent significant trends at $95 \%$ confidence interval

precipitation extremes (Rajbhandari et al. 2015; Wijngaard et al. 2017; Ali et al. 2019).

\section{Conclusion}

In order to understand the vulnerability of river basins due to climate change, this study analyzed the impact of climate change on extreme climate indices in the Jhelum 
River basin using observed data of 15 stations for past climate extremes. For future trends of climate extremes, the ensemble mean of three Global Climate Models from CMIP5 were used with two Representative Concentration Pathways (RCP) scenarios. Therefore, Statistical Downscaling Model (SDSM) has been used to downscale the future precipitation and temperature. The selection of most appropriate predictors for the calibration of SDSM was very challenging in the study area due to complex terrain. In general, the performance of SDSM was good during validation with NCEP and GCMs outputs (Saddique et al. 2019). The results reveal that there is a warming trend in temperature indices and increasing trends in precipitation indices at most of the stations of basin.

The outcomes showed that the frequency of summer days, warm nights and days increased for the projected climate across the River basin. On the other hand, the number of cold days' and nights decreased at all the stations of basin under both RCPs scenarios. However, the magnitudes of trends under RCP8.5 was higher as compared to RCP4.5. Furthermore, intensity indices (warmest days, warmest nights, coldest days and coldest nights) also showed positive trends. The decadal increment in warmest days and nights were projected to be higher than coldest nights (TNn) and coldest days (TXn) for both scenarios. Under RCP8.5, the warmest nights exhibited significant positive trends with a mean increase of $0.60{ }^{\circ} \mathrm{C}$ per decade over the catchment for future time slice (2061-2090). This shows, there is warming across the Jhelum River basin at the end of twenty-first century.

The results of precipitation extremes indices indicated an increasing trend in annual total precipitation amount, maximum 1-day precipitation, maximum 5-day precipitation, heavy precipitation days, precipitation in very wet days, and simple daily intensity index over the JRB. During the future time period (2061-2090), the magnitudes of all precipitation indices except precipitation during very wet days would increase but the average increase expected to be smaller as compared to baseline period. In general, SDSM was able to reasonably simulate the extremes indices in the JRB. However, much more research is needed for a clearer understanding of the future changes in the climate and uncertainties (downscaling methods and GCMs) associated with climate projections. Therefore, the authors would like to suggest further assessment of the study area using large ensembles of GCMs/RCMs or the Coordinated Regional Climate Downscaling Experiments (CORDEX). CORDEX is developed to improve the regional downscaling techniques and achieve valuable conclusions in future regional climate projections.

Overall, the results of present study help to illustrate the Jhelum River basin under the risk of climate extreme events will serve as a convenient resource for the assessment of climate change impacts on human health, agriculture, environment and water resources in order to enhance regional decision-making, adaptation and strategic planning.

Acknowledgements Open Access funding provided by Projekt DEAL. The first author was financially supported by the doctoral scholarship from the Higher Education Commission of Pakistan (HEC) Pakistan and German Academic Exchange Service (DAAD) Germany. The authors wish to acknowledge the Pakistan Meteorological Department (PMD) and Indian Meteorological Department (IMD) for providing data used in this study. The authors thank the two anonymous reviewers for their constructive comments and suggestions, which helped us to improve the manuscript considerably.

Open Access This article is licensed under a Creative Commons Attribution 4.0 International License, which permits use, sharing, adaptation, distribution and reproduction in any medium or format, as long as you give appropriate credit to the original author(s) and the source, provide a link to the Creative Commons licence, and indicate if changes were made. The images or other third party material in this article are included in the article's Creative Commons licence, unless indicated otherwise in a credit line to the material. If material is not included in the article's Creative Commons licence and your intended use is not permitted by statutory regulation or exceeds the permitted use, you will need to obtain permission directly from the copyright holder. To view a copy of this licence, visit http://creativecommons. org/licenses/by/4.0/.

\section{References}

Abatan AA, Abiodun BJ, Gutowski WJ, Rasaq-Balogun SO (2018) Trends and variability in absolute indices of temperature extremes over Nigeria: linkage with NAO. Int $\mathrm{J}$ Climatol 38(2):593-612. https://doi.org/10.1002/joc.5196

Abbasnia M, Toros H (2018) Analysis of long-term changes in extreme climatic indices: a case study of the Mediterranean climate, Marmara Region, Turkey. Pure Appl Geophys 175(11):3861-3873. https://doi.org/10.1007/s00024-018-1888-8

Adyeri OE, Lawin AE, Laux P, Ishola KA, Ige SO (2019) Analysis of climate extreme indices over the Komadugu-Yobe basin, Lake Chad region: past and future occurrences. Weather Clim Extremes 23:100194. https://doi.org/10.1016/j.wace.2019. 100194

Ali SHB, Shafqat MN, Eqani SAMA, Shah STA (2019) Trends of climate change in the upper Indus basin region, Pakistan: implications for cryosphere. Environ Monit Assess 191:51. https://doi.org/10.1007/s10661-018-7184-3

Archer DR, Fowler HJ (2008) Using meteorological data to forecast seasonal runoff on the River Jhelum, Pakistan. J Hydrol 361(1-2):10-23. https://doi.org/10.1016/j.jhydrol.2008.07.017

Asian Development Bank (ADB), World Bank (2010) Pakistan floods 2010 damage and needs assessment. Pakistan Development Forum, Islamabad-Pakistan. Published on 12 Nov 2010. To be accessed from http://reliefweb.int/report/pakistan/pakistanfloods-2010-preliminary-damage-and-needs-assessment

Bao J, Feng J, Wang Y (2015) Dynamical downscaling simulation and future projection of precipitation over China. J Geophys Res Atmos 120:8227-8243. https://doi.org/10.1002/2015JD023275

Casanueva Vicente A, Rodríguez Puebla C, Frías Domínguez MD, González Reviriego N (2014) Variability of extreme precipitation over Europe and its relationships with teleconnection patterns. Hydrol Earth Syst Sci 18:709-725 
Chen L, Ma Z, Li Z, Wu L, Flemke J, Li Y (2018) Dynamical downscaling of temperature and precipitation extremes in china under current and future climates. Atmosp Ocean 56(1):55-70. https://doi.org/10.1080/07055900.2017.1422691

Cheong WK, Timbal B, Golding N, Sirabaha S, Kwan KF, Cinco TA, Archevarahuprok B, Vo VH, Gunawan D, Han S (2018) Observed and modelled temperature and precipitation extremes over Southeast Asia from 1972 to 2010. Int J Climatol 38(7):3013-27. https://doi.org/10.1002/joc.5479

Diaz-Nieto J, Wilby RL (2005) A comparison of statistical downscaling and climate change factor methods: impacts on low flows in the River Thames, United Kingdom. Clim Change 69:245-268

Fenta Mekonnen D, Disse M (2018) Analyzing the future climate change of Upper Blue Nile River basin using statistical downscaling techniques. Hydrol Earth Syst Sci 22(4):2391-2408. https://doi.org/10.5194/hess-22-2391-2018

Feyissa G, Zeleke G, Bewket W, Gebremariam E (2018) Downscaling of future temperature and precipitation extremes in Addis Ababa under climate change. Climate 6(3):58. https://doi.org/10. 3390/cli6030058

Frias MD, Mingues R, Gutierrez JM, Mendez FJ (2012) Future regional projections of extreme temperatures in Europe: a nonstationary seasonal approach. Clim Change 113:371-392. https://doi.org/10.1007/s10584-011-0351

Gu H, Wang G, Yu Z, Mei R (2012) Assessing future climate changes and extreme indicators in east and south Asia using the RegCM4 regional climate model. Clim Change 114(2):301-317. https:// doi.org/10.1007/s10584-012-0411

Hartmann H, Buchanan H (2014) Trends in extreme precipitation events in the Indus River Basin and flooding in Pakistan. Atmos Ocean 52(1):77-91. https://doi.org/10.1080/07055900.2013. 859124

Huang J, Zhang J, Zhang Z, Xu C, Wang B, Yao J (2011) Estimation of future precipitation change in the Yangtze River basin by using statistical downscaling method. Stoch Env Res Risk Assess 25(6):781-792. https://doi.org/10.1007/s00477-010-0441-9

IPCC (2013) Climate change 2013: the physical science basis. In: Contribution of Working Group I to the Fifth Assessment Report of the Intergovernmental Panel on Climate Change. Intergovernmental Panel on Climate Change, Working Group I Contribution to the IPCC Fifth Assessment Report (AR5). Cambridge Univ Press, New York, p 1535. https://doi.org/10.1029/ 2000JD000115

Islam SU, Rehman N, Sheikh MM (2009) Future change in the frequency of warm and cold spells over Pakistan simulated by the PRECIS regional climate model. Clim Change 94(1-2):35-45. https://doi.org/10.1007/s10584-009-9557-7

Katz RW, Brown BG (1992) Extreme events in a changing climate: variability is more important than averages. Clim Change 3(21):289-302. https://doi.org/10.1007/BF00139728

Kendall MG (1975) Rank correlation methods, 4th edn. Charles Griffin, London

Mahmood R, Babel MS (2014) Future changes in extreme temperature events using the statistical downscaling model (SDSM) in the trans-boundary region of the Jhelum river basin. Weather Clim Extremes 5(1):56-66. https://doi.org/10.1016/j.wace.2014. 09.001

Mann HB (1945) Non-parametric tests against trend. Econometrica 13:245-259

Meehl GA, Stocker TF, Collins WD, Friedlingstein P, Gaye AT, Gregory JM, Kitoh A, Knutti R, Murphy JM, Noda A, Raper SCB, Watterson IG, Weaver AJ, Zhao Z-C (2007) Global climate projections. In: Climate change 2007: the physical science basis. Contribution of Working Group I to the Fourth
Assessment Report of the Intergovernmental Panel on Climate Change

Moss RH, Edmonds JA, Hibbard KA, Manning MR, Rose SK, Van Vuuren DP, Carter TR, Emori S, Kainuma M, Kram T, Meehl GA, Wilbanks TJ (2010) The next generation of scenarios for climate change research and assessment. Nature 463(7282):747-756. https://doi.org/10.1038/nature08823

Ongoma V, Chen H, Omony GW (2018) Variability of extreme weather events over the equatorial East Africa, a case study of rainfall in Kenya and Uganda. Theor Appl Climatol 131(1-2):295-308. https://doi.org/10.1007/s00704-016-1973-9

Pei F, Wu C, Qu A, Xia Y, Wang K, Zhou Y (2017) Changes in extreme precipitation: a case study in the middle and lower reaches of the Yangtze River in China. Water 9(12):943. https:// doi.org/10.3390/w9120943

Peng Y, Zhao X, Wu D, Tang B, Xu P, Du X, Wang H (2018) Spatiotemporal variability in extreme precipitation in China from observations and projections. Water 10(8):1-17. https://doi. org/10.3390/w10081089

Peterson TC (2005) Climate change indices. WMO Bull 54(2):83-86

Rajbhandari R, Shrestha AB, Kulkarni A, Patwardhan Sk, Bajracharya SR (2015) Projected changes in climate over the Indus river basin using a high resolution regional climate model (PRECIS). Clim Dyn 44:339-357. https://doi.org/10.1007/ s00382-014-2183-8

Rashid MM, Beecham S, Chowdhury RK (2017) Simulation of extreme rainfall and projection of future changes using the GLIMCLIM model. Theor Appl Climatol 130(1-2):453-466. https://doi.org/10.1007/s00704-016-1892-9

Rehman A, Jingdong L, Du Y, Khatoon R, Wagan SA, Nisar SK (2015) Flood disaster in Pakistan and its impacts on agriculture growth (a review). Glob Adv Res J Agric Sci 4(12):827-830

Roxy MK, Ghosh S, Pathak A, Athulya R, Mujumdar M, Murtugudde R, Rajeevan M (2017) A threefold rise in widespread extreme rain events over central India. Nat Commun 8(1):1-11. https:// doi.org/10.1038/s41467-017-00744-9

Saddique N, Bernhofer C, Kronenberg R, Usman M (2019) Downscaling of CMIP5 models output by using statistical models in a data scarce mountain environment (Mangla Dam Watershed), Northern Pakistan. Asia-Pac J Atmos Sci 55(4):717-735. https:// doi.org/10.1007/s13143-019-00111-2

Saleem M, Shah SZ, Azam S (2018) Heat wave killings in Pakistan and possible strategies to prevent the future heat wave fatalities. Res Rev Healthc Open Access J. https://doi.org/10.32474/ RRHOAJ.2018.01.000113

Salvador MA, de Brito JIB (2018) Trend of annual temperature and frequency of extreme events in the MATOPIBA region of Brazil. Theor Appl Climatol 133(1-2):253-261. https://doi.org/10.1007/ s00704-017-2179-5

Sharma A, Goyal MK (2020) Assessment of the changes in precipitation and temperature in Teesta River basin in Indian Himalayan Region under climate change. Atmos Res 231:104670. https://doi.org/10.1016/j.atmosres.2019.104670

Sharma S, Mujumdar P (2017) Increasing frequency and spatial extent of concurrent meteorological droughts and heatwaves in India. Sci Rep 7(1):1-9. https://doi.org/10.1038/s41598-01715896-3

Sillmann J, Kharin VV, Zhang X, Zwiers FW, Bronaugh D (2013) Climate extremes indices in the CMIP5 multimodel ensemble: part 1. Model evaluation in the present climate. J Geophys Res Atmos 118(4):1716-1733. https://doi.org/10.1002/jgrd.50203

Turco M, Quintana-Seguí P, Llasat MC, Herrera S, Gutiérrez JM (2011) Testing MOS precipitation downscaling for ENSEMBLES regional climate models over Spain. J Geophys Res Atmos 116(18):1-14. https://doi.org/10.1029/2011JD016166 
Wilby RL, Dawson CW (2004) Using SDSM Version 3. 1-a decision support tool for the assessment of regional climate change impacts User Manual. Environment, 1-67

Wilby RL, Dawson CW (2013) The statistical downscaling model: insights from one decade of application. Int $\mathrm{J}$ Climatol 33(7):1707-1719. https://doi.org/10.1002/joc.3544

Wijngaard RR, Lutz AF, Nepal S, Khanal S, Pradhananga S, Shrestha AB, Immerzeel WW (2017) Future changes in hydro-climatic extremes in the Upper Indus, Ganges, and Brahmaputra River basins. PLoS ONE 12(12): e0190224. https://doi.org/10.1371/ journal.pone.0190224
Zhang X, Yang F (2004) Rclimdex, User manual

Zhang Y, You Q, Chen C, Ge J (2016) Impacts of climate change on streamflows under RCP scenarios: a case study in Xin River Basin, China. Atmos Res 178-179:521-534. https://doi.org/10. 1016/j.atmosres.2016.04.018

Publisher's Note Springer Nature remains neutral with regard to jurisdictional claims in published maps and institutional affiliations. 